\title{
Endomycorrhizae Enhance Growth of Shrub Species in Processed Oil Shale and Disturbed Native Soil
}

\author{
C.A. CALL AND C.M. MCKELL
}

\section{Abstract}

A greenhouse experiment was conducted to determine if the inoculation of native shrubs with vesicular-arbuscular mycorrhizal (VAM) fungi would provide plants better adapted for a minimaltreatment revegetation program for processed oil shale and disturbed native soil. Seedlings of fourwing saltbush \{Atriplex canescens (Pursh.) Nutt.), big sagebrush (Artemisia tridentata Nutt. ssp. wyomingensis), rubber rabbitbrush (Chrysothamnus nauseosus (Pall.) Britton var. nauseosus\}, and greasewood \{Sarcobatus vermiculatus (Hook.) Torr. var. vermiculatus\} were inoculated with Glomus fasciculatum (Thaxter sensu Gerdemann) Gerdemann and Trappe, and Glomus mosseae (Nicol. and Gerd.) Gerdemann and Trappe. Inoculated and noninoculated plants were transplanted into Paraho processed oil shale and disturbed native soil in a containerized system. Plants inoculated with VAM fungi had greater shoot biomass and phosphorus $(P)$ contents than noninoculated plants in both media. Inoculation with VAM fungi had a variable effect on the nitrogen $(N)$ contents of plants in both media. When fertilized with $34 \mathrm{~kg} / \mathrm{ha} N$ and $P$, inoculated plants were more effective in taking up applied $P$ than noninoculated plants. Mycorrhizal infection levels were greatly reduced when inoculated plants were grown in processed shale.

After mining, crushing, and retorting at $500 \mathrm{C}$, processed oil shale is a highly saline, highly alkaline, biologically sterile, nutrient deficient material with no structure (McKell 1976). When untreated, processed shale is a poor plant growth medium (Schmehl and McCaslin 1973). With intensive treatment (leaching salts with large amounts of water, fertilization, topsoiling, mulching, and periodic supplemental irrigation), a variety of plant species can be established directly on processed shale (Block and Kilburn 1973, Harbert and Berg 1974). However, the cost of such treatments would be high considering the large deposits of processed shale expected from commercial oil shale production. A rehabilitation strategy for processed shale disposal piles and disturbed soils should make logical, effective use of the limited natural resources available for rehabilitation in arid regions (McKell 1976). Such a strategy must work within the environmental constraints of the affected ecosystems, and could be more cost effective than those strategies that recommended extensive modification of the spent shale. Indigenous end omycorrhizal fungi could be integrated into this rehabilitation strategy.

Endomycorrhizal fungi are beneficial fungi that form symbiotic associations (endomycorrhizae) with the roots of higher plants. One group of endomycorrhizac, vesicular-arbuscular mycorrhizae (VAM), are found on the majority of plant species in semiarid oil shale regions (Call and McKell 1982, Reeves et al. 1979). Vesiculararbuscular mycorrhizae enhance plant absorption of phosphorus and other elements, enhance water uptake and transport in plants, and allow plants to withstand high temperatures (Gerdemann

\footnotetext{
Authors are assistant professor, Range Science Department, Texas A\&M University, College Station 77843; and vice president for research, Native Plants Inc., Salt Lake City, Utah 84108. At the time of the research, the authors were, respectively, research assistant and director, Institute for Land Rehabilitation, Utah State University, Logan.

Research was funded in part by a grant from the White River Shale Project, Vernal, Utah.

Manuscript accepted September 12, 1984.
}

1975). Vesicular-arbuscular mycorrhizae have been shown to increase the survival and growth of shrub species on coal mine spoil material in field and greenhouse studies in New Mexico (Aldon 1978).

In view of the adaptive features of VAM on unfavorable sites, and the unfavorable characteristics of processed shale as a plant growth medium, a greenhouse experiment was conducted to determine if the inoculation of selected, container-grown, native shrubs with VAM fungi would provide plants better adapted for a minimal-treatment revegetation program for processed oil shale and disturbed native soil.

\section{Materials and Methods}

Seedlings of fourwing saltbush \{Atriplex canescens (Pursh.) Nutt.\}, big sagebrush (Artemisia tridentata Nutt. ssp. wyomingensis), rubber rabbitbrush (Chrysothamnus nauseosus (Pall.) Britton var. nauseosus\}, and greasewood \{Sarcobatus vermiculatus (Hook.) Torr. var. vermiculatus\} were inoculated with VAM fungi in a containerized system.

Fungal inoculum was developed from spores in soil samples collected beneath fourwing saltbush, big sagebrush, rubber rabbitbrush, and greasewood plants on a semiarid site $80 \mathrm{~km}$ southeast of Vernal, Utah. Spores were collected from the soil samples using a wet-sieving and decanting technique (Gerdemann and Nicolson 1963), and VAM fungi were identified according to Gerdemann and Trappe (1974). The 2 spore types most commonly observed in the wet-sieved soil were identified as Glomus faciculatum (Thaxter sensu Gerdemann) Gerdemann and Trappe, and Glomus mosseae (Nicl. and Gerd.) Gerdemann and Trappe. Spores were surface sterilized in $0.05 \%$ sodium hypochlorite for 10 minutes, rinsed 3 times in distilled water, and introduced into trap plant cultures of sudan grass (Sorghum vulgare Pers.). After 4 months, pot culture medium from these initial trap plant cultures was used as inoculum for mass trap plant cultures of sudan grass. After 4 months pot culture medium from mass trap plant cultures was used to inoculate the container medium. Approximately $250 \mathrm{cc}$ of this pot culture inoculum were placed in 2 layers within sterilized container medium (peatmoss-perlite-sand-soil 1:1:2:4 V/V) in $5 \times 5 \times 25-\mathrm{cm}$ parafin-coated paperboard containers.

After 6 months, inoculated and noninoculated plants were transplanted into $15 \mathrm{~cm}$ (diameter) by $40 \mathrm{~cm}$ PVC plastic containers filled with $6.5 \mathrm{~kg}$ of $6.4-\mathrm{mm}$ screened, Paraho processed oil shale ( $10 \%$ moisture by weight) or $7.5 \mathrm{~kg}$ of $6.4-\mathrm{mm}$ screened native soil ( $10 \%$ moisture by weight). Samples of the Paraho processed oil shale and disturbed native soil from Anvil Points, Colo., were analyzed for texture, pH, electrical conductivity $\left(E_{e}\right)$, phosphorus $(\mathrm{P})$, nitrate-nitrogen $\left(\mathrm{NO}_{\mathfrak{Z}}\right)$, potassium $(\mathrm{K})$, sodium $(\mathrm{Na})$, calcium $(\mathrm{Ca})$, and magnesium $(\mathrm{Mg})$ by the Soil Analysis Laboratory at Utah State University (Table 1).

Two fertilizer regimes (nonfertilized control and $34 \mathrm{~kg} / \mathrm{ha} \mathrm{N}$ and P) were imposed after the shrub species were transplanted into the processed shale and disturbed soil media. In the $34 \mathrm{~kg} /$ ha $\mathrm{N}$ and $P$ fertilizer treatment, each PVC container was fertilized with $0.20 \mathrm{~g}$ ammonium nitrate $\left(\mathrm{NH}_{4} \mathrm{NO}_{3}\right)$ and $0.30 \mathrm{~g}$ monocalcium phosphate $\left\{\mathrm{Ca}\left(\mathrm{h}_{2} \mathrm{PO}_{4}\right)_{2}\right\}$. A $2.5-\mathrm{cm}$ layer of sterile, fine sand was placed on top 
of the plant growth media to reduce evaporation of water and capillary rise of dissolved salts. Plants in each treatment were watered via water access tubes (1.25-cm diameter PVC plastic pipc with $2.7-\mathrm{mm}$ diameter holes) to facilitate movement of water downward through the media without disturbing the sand mulch. The total combined weight of the plastic container, media, sand mulch, water access tubes and soil plug plus seedling was determined for each container. This weight, corresponding to approximately a $10 \%$ soil or shale water content (by weight), was maintained throughout the experiment by additions of distilled water every other day. No weight corrections were made to compensate for plant growth. Greenhouse air temperatures ranged from 15.5 to $32^{\circ} \mathrm{C}$ over the duration of the experiment.

Shoot biomass, $P$ and $N$ contents of shoot material, and mycorrhizal development were determined at the end of the 3-month growing period. Shoot biomass (leaves plus stems) was harvested in the soil/shale surface, dried at $65^{\circ} \mathrm{C}$ for 48 hours, weighed, and ground in a Wiley Mill ( $1-\mathrm{mm}$ mesh screen) prior to nutrient analysis. One-half gram samples were digested according to the procedures of Chapman and Pratt (1961). Phosphorus content was determined by atomic absorption spectrophotometry. Total $\mathbf{N}$ content was determined by a modified Kjeldahl method (Horowitz 1965). Nitrogen and P contents were expressed in percent of dry plant material. Roots were cleaned of debris, cut into $1-\mathrm{cm}$ segments, cleared in $10 \% \mathrm{KOH}$, and stained in $0.05 \%$ trypan-blue in lacto-phenol (Phillips and Hayman 1970). Stained root segments were mounted in clear lacto-phenol and examined under a compound microscope at $140 \times$ for the presence or absence of VAM infection. A root segment was considered infected if it contained arbuscules, vesicles, or peletons, or any combination of the three. Percentage infection was calculated as the number of segments with any infection out of a random sample of 100 segments.

The experiment was arranged in a completely randomized, three-way factorial design with 5 plants per treatment for each of the 4 species. Analysis of variance and Duncan's multiple range test
$(P<0.05)$ were utilized in the interpretation of shoot biomass data (Little and Hills 1972). Phosphorus and $\mathrm{N}$ data were not statistically analyzed because shoot biomass samples were too small for individual chemical analysis, therefore, samples were pooled for each treatment prior to analysis.

\section{Results and Discussion}

Plants inoculated with VAM fungi had greater shoot biomass than noninoculated plants in both processed shale and disturbed soil (Table 2). The stimulation of shoot biomass production was most evident in the disturbed soil, where inoculated big sagebrush and fourwing saltbush plants had significantly greater biomass than noninoculated controls in fertilized and nonfertilized treatments. Inoculated, nonfertilized fourwing saltbush plants had significantly greater shoot biomass than noninoculated, fertilized controls in the disturbed soil.

Increased growth associated with VAM infection in nutrient deficient soils and spoils has been attributed to enhanced nutrient uptake, especially the uptake of $P$ (Gerdemann 1975). In all 4 species, inoculated plants had higher $P$ contents than noninoculated controls in both processed shale and disturbed soil (Table 3). Vesicular-arbuscular mycorrhizae help plants compensate for deficiencies of immobile nutrients such as phosphate by exploring a greater volume of soil than roots alone, and by presenting a greater surface area for phosphate uptake (Bowen et al. 1975). In addition to increasing the surface area of infected roots, VAM fungi take up phosphate much more rapidly than nonmycorrhizal roots and transfer it rapidly to the host plant (Bowen et al. 1975).

When fertilized with $34 \mathrm{~kg} /$ ha $N$ and $P$, inoculated plants were more effective in taking up applied $\mathrm{P}$ to increase shoot biomass. Menge (1980) suggested that VAM fungi could be thought of as "biotic fertilizers" because they can increase the efficiency of $P$ fertilizer use as they did in this experiment. The inoculation of container-grown shrubs with VAM fungi could reduce the substantial amounts of $P$ fertilizer which may be used in the revegeta-

Table 1. Chemical properties of the Paraho processed oil shale and disturbed native soil (from Anvil Points, Colorado) used as container media in the greenhouse study.

\begin{tabular}{|c|c|c|c|c|c|c|c|}
\hline \multirow[b]{2}{*}{ Media } & \multirow[b]{2}{*}{$\mathrm{pH}^{\prime}$} & \multirow{2}{*}{$\begin{array}{c}\mathrm{EC}_{\mathrm{e}}^{2} \\
(\mathrm{mmhos} / \mathrm{cm})\end{array}$} & \multicolumn{2}{|c|}{$\mathrm{meq} / \mathrm{l}$} & \multicolumn{3}{|c|}{ ppm } \\
\hline & & & $\mathrm{Na}^{3}$ & $\mathrm{Ca}+\mathrm{Mg}^{3}$ & $\mathrm{p}^{4}$ & $\mathrm{No}_{3}^{5}$ & $\mathbf{K}^{3}$ \\
\hline Paraho processed shale & 8.7 & 10.5 & 61.0 & 74.0 & 3.0 & 1.4 & 121 \\
\hline Disturbed native soil & 7.9 & 6.7 & 67.4 & 26.5 & 3.1 & 8.7 & 80 \\
\hline
\end{tabular}

'Based on saturated paste.

2Based on saturation extract.

${ }^{3}$ Ammonium acetate extractable.

4Sodium bicarbonate extractable.

sPhenodisulfonic acid extractable.

Table 2. Mean shoot biomass of big sagebrush, fourwing saltbush, rubber rabbitbrush, and greasewood after three-month growing period in the greenhouse, showing the interactions between media treatments, inoculation treatments, and fertilization treatments for each species.

\begin{tabular}{|c|c|c|c|c|}
\hline \multirow[b]{2}{*}{ Treatment $^{1}$} & \multicolumn{4}{|c|}{ Biomass (g/plant) } \\
\hline & Big sagebrush & Fourwing saltbush & Rubber rabbitbrush & Greasewood \\
\hline $\begin{array}{l}\text { Shale } \\
\text { Non-inoculated, non-fert. } \\
\text { Inoculated, non-fertilized } \\
\text { Non-inoculated, fertilized } \\
\text { Inoculated, fertilized }\end{array}$ & $\begin{array}{l}0.76 \mathrm{~d} \\
1.04 \mathrm{~cd}^{2} \\
0.88 \mathrm{~d} \\
1.06 \mathrm{~cd}\end{array}$ & $\begin{array}{l}0.64 \mathrm{e} \\
0.92 \mathrm{e} \\
1.28 \mathrm{~d} \\
0.64 \mathrm{c}\end{array}$ & $\begin{array}{l}0.53 c d \\
0.54 c d \\
0.32 d \\
0.44 c d\end{array}$ & $\begin{array}{l}0.46 \mathrm{~d} \\
0.54 \mathrm{~cd} \\
0.52 \mathrm{~cd} \\
0.70 \mathrm{~cd}\end{array}$ \\
\hline $\begin{array}{l}\text { Soil } \\
\text { Non-inoculated, non-fert. } \\
\text { Inoculated, non-fertilized } \\
\text { Non-inoculated, fertilized } \\
\text { Inoculated, fertilized }\end{array}$ & $\begin{array}{l}1.36 \mathrm{bc} \\
2.48 \mathrm{a} \\
1.56 \mathrm{~b} \\
2.89 \mathrm{a}\end{array}$ & $\begin{array}{l}1.31 \mathrm{~d} \\
1.73 \mathrm{c} \\
2.34 \mathrm{~b} \\
3.52 \mathrm{a}\end{array}$ & $\begin{array}{l}0.71 \mathrm{bcd} \\
0.92 \mathrm{bc} \\
1.09 \mathrm{~b} \\
2.76 \mathrm{a}\end{array}$ & $\begin{array}{l}0.76 \mathrm{~cd} \\
1.00 \mathrm{bc} \\
1.42 \mathrm{ab} \\
1.69 \mathrm{a}\end{array}$ \\
\hline
\end{tabular}

IShale $=$ Paraho processed oil shale, soil $=$ disturbed native soil, inoculated $=$ inoculation with VAM fungi, and fertilized $=34 \mathrm{~kg} /$ ha $\mathrm{N}$ and $\mathrm{P}$.

${ }^{2}$ Means within columns followed by the same letter are not significantly different $(P<0.05)$ according to Duncan's multiple range test. 
Table 3. Phosphorus content of shoot biomass of big sagebrush, fourwing saltbush, rubber rabbitbrush, and greasewood after a three-month growing period in the greenhouse in different media, inoculation, and fertilization treatments.

\begin{tabular}{|c|c|c|c|c|}
\hline \multirow[b]{2}{*}{ Treatment ${ }^{\prime}$} & \multicolumn{4}{|c|}{ Phosphorus $(\%)^{2}$} \\
\hline & Big sagebrush & Fourwing saltbush & Rubber rabbitbrush & Greasewood \\
\hline \multicolumn{5}{|l|}{ Shale } \\
\hline Non-inoculated, non-fert. & .148 & .067 & .057 & .115 \\
\hline Inoculated, non-fertilized & .169 & .078 & .081 & .128 \\
\hline Non-inoculated, fertilized & .196 & .107 & .056 & .132 \\
\hline Inoculated, fertilized & .205 & .122 & .092 & .133 \\
\hline \multicolumn{5}{|l|}{ Soil } \\
\hline Non-inoculated, non-fert. & .360 & .098 & .110 & .101 \\
\hline Inoculated, non-fertilized & .385 & .119 & .122 & .103 \\
\hline Non-inoculated, fertilized & .493 & .120 & .124 & .133 \\
\hline Inoculated, fertilized & .528 & .136 & .267 & .145 \\
\hline
\end{tabular}

iShale = Paraho processed oil shale, soil = disturbed native soil, inoculated $=$ inoculation with VAM fungi, and fertilized $=34 \mathrm{~kg} / \mathrm{ha} \mathbf{N}$ and $P$.

${ }^{2}$ Composite value of five samples pooled for each treatment prior to phosphorus analysis; data were not statistically analyzed.

Table 4. Total nitrogen content of shoot biomass of big sagebrush, fourwing saltbush, rubber rabbitbrush, and greasewood after a three-month growing period in the greenhouse in different media, inoculation, and fertilization treatments.

\begin{tabular}{|c|c|c|c|c|}
\hline \multirow[b]{2}{*}{ Treatment' } & \multicolumn{4}{|c|}{ Nitrogen $(\%)^{2}$} \\
\hline & Big sagebrush & Fourwing saltbush & Rubber rabbitbrush & Greasewood \\
\hline \multicolumn{5}{|l|}{ Shale } \\
\hline Non-inoculated, non fert. & 1.81 & 1.17 & 1.37 & .82 \\
\hline Inoculated, non-fertilized & 1.73 & 1.39 & 1.37 & 1.02 \\
\hline Non-inoculated, fertilized & 2.26 & 1.44 & 2.18 & 1.20 \\
\hline Inoculated, fertilized & 2.19 & 1.63 & 2.04 & 1.34 \\
\hline \multicolumn{5}{|l|}{ Soil } \\
\hline Non-inoculated, non-fert. & 2.23 & 1.55 & 1.75 & 1.68 \\
\hline Inoculated, non-fertilized & 2.70 & 1.63 & 1.72 & 1.35 \\
\hline Non-inoculated, fertilized & 2.84 & 1.90 & 2.25 & 2.00 \\
\hline Inoculated, fertilized & 2.80 & 2.06 & 2.47 & 1.54 \\
\hline
\end{tabular}

IShale = Paraho processed oil shale, soil $=$ disturbed native soil, inoculated $=$ inoculation with VAM fungi, and fertilized $=34 \mathrm{~kg} /$ ha $\mathrm{N}$ and $P$.

${ }^{2}$ Composite value of five samples pooled for each treatment prior to nitrogen analysis; data were not statistically analyzed.

Table 5. Percent VAM fungal infection in roots of big sagebrush, fourwing saltbush, rubber rabbitbrush, and greasewood after a three-month growing period in the greenhouse in different media, inoculation, and fertilization treatments.

\begin{tabular}{|c|c|c|c|c|}
\hline \multirow[b]{2}{*}{ Treatment ${ }^{\mathrm{I}}$} & \multicolumn{4}{|c|}{ (\% Infection) } \\
\hline & Big sagebrush & Fourwing saltbush & Rubber rabbitbrush & Greasewood \\
\hline \multicolumn{5}{|l|}{ Shale } \\
\hline Non-inoculated, non-fert. & 0.0 & 0.0 & 0.0 & 0.0 \\
\hline Inoculated, non-fertilized & 11.2 & 4.5 & 9.4 & 0.0 \\
\hline Non-inoculated, fertilized & 0.0 & 0.0 & 0.0 & 0.0 \\
\hline Inoculated, fertilized & 8.7 & 5.6 & 8.0 & 0.0 \\
\hline \multicolumn{5}{|l|}{ Soil } \\
\hline Non-inoculated, non-fert. & 6.0 & 0.0 & 2.4 & 0.0 \\
\hline Inoculated, non-fertilized & 48.0 & 13.1 & 44.0 & 0.0 \\
\hline Non-inoculated, fertilized & 0.0 & 0.0 & 0.0 & 0.0 \\
\hline Inoculated, fertilized & 38.8 & 10.6 & 37.0 & 0.0 \\
\hline
\end{tabular}

iShale $=$ Paraho processed oil shale, soil $=$ disturbed native soil, inoculated $=$ inoculation with VAM fungi, and fertilized $=34 \mathrm{~kg} / \mathrm{ha} \mathrm{N}$ and $\mathrm{P}$.

tion of processed oil shale disposal piles.

Inoculation of the 4 shrub species with VAM fungi had a variable effect on the uptake of $\mathrm{N}$ in both media (Table 4). Other studies indicate that nitrate is the major form of $\mathrm{N}$ taken up and assimilated by several salt desert shrub species under greenhouse conditions (Institute for Land Rehabilitation 1979). Due to the mobility of this form of $\mathrm{N}$ in the soil, plant uptake may not be improved by VAM fungi under greenhouse conditions when soil water is not severely limited. Even though VAM may not directly enhance the uptake of applied $\mathbf{N}$ under these conditions, $\mathrm{N}$ fertilization rates can be reduced in the presence of VAM. This conservation of $N$ is probably due to an increased efficiency of $\mathbf{N}$ utilization resulting from the improved $P$ nutritional status of the mycorrhizal plant (Menge 1980).

Plants growing in disturbed soil had greater shoot biomass (Table 2), $\mathrm{P}$ contents (Table 3), and $\mathrm{N}$ contents (Table 4) than plants growing in processed shale. The decrease in shoot biomass in processed shale can be attributed to the lower water holding capacity, higher electrical conductivity, higher $\mathrm{pH}$, and greater nutrient deficiency of the spent shale (Table 1).

The extent of mycorrhizal infection is of importance when studying the influence of VAM on the host plant. At the time of transplanting into the processed shale, inoculated plants of big sagebrush, rubber rabbitbrush, fourwing saltbush, and greasewood 
had respective infection percentages of $46 \%, 40 \%, 12 \%$, and $0 \%$. With the exception of greasewood, there were slight increases in infection of inoculated shrubs when transplanted into disturbed soil, and substantial reductions in infection when transplanted into processed shale (Table 5). Vesicular-arbuscular mycorrhizae have been reported for greasewood on undisturbed sites in the Red Desert of Wyoming, but infection was low (0-7\%) and not as common as with other shrubs examined (Miller 1979). Watersoluble, retorted oil shale constituents probably contributed to the decline in infection of inoculated plants growing in processed shale (DeVore and Christensen 1979, Hersman and Klein 1979). The application of $34 \mathrm{~kg} / \mathrm{ha} \mathrm{N}$ and $\mathrm{P}$ had little effect on infection in the 4 shrub species.

Even with low percentages, big sagebrush, fourwing saltbush and rubber rabbitbrush still displayed positive growth responses. High infection may not be a prerequisite for growth responses in all plants inoculated with VAM fungi. Abundant VAM can be present with no subsequent detectable growth difference and conversely, a low infection level can sometimes induce marked growth stimulation (Daft and Nicholson 1966).

Microorganisms involved in biogeochemical cycling processes, soil formation and soil stabilization are initially absent in sterile, processed shale, and it may take several years for a diverse microbial population, essential for developing plant-soil systems, to build up naturally. Vesicular-arbuscular mycorrhizal fungi by themselves cannot restore mineral cycling processes, but they can enhance the growth of native plants in the short term, which may in turn create a more favorable environment for the development of ecosystem processes. Nutrients and organic matter in plant litter will encourage soil development in the surface horizon. Plant cover will reduce spoil erosion and create more favorable sites for seedling establishment. In addition to making processed shale a more tractable medium for plant establishment, VAM can enhance the growth of later seral shrub species on soils disturbed by associated mining and reclamation activities.

\section{Literature Cited}

Aldon, E.F. 1978. Endomycorrhizae enhance shrub growth and survival on mine spoils, p. 174-179. In: R.A. Wright (ed.), The reclamation of disturbed arid lands. University of New Mexico Press, Albuquerque, New Mex.

Bowen, G.D., D.I. Bevege, and B. Mosse. 1975. Phosphate physiology of vesicular-arbuscular mycorrhizas, p. 241-260. In: F.E. Sanders, B. Mosse, and P.B. Tinker (eds.), Endomycorrhizas. Academic Press, New York.

Block, M.B., and P.D. Kilburn. 1973. Processed shale revegetation studies. Colony Development Operation, Atlantic Richfield Company, Denver, Colo.
Call, C.A., and C.M. McKell. 1982. Vesicular-arbuscular mycorrhizae-A natural revegetation strategy for disposed processed oil shale. Reclam. Reveg. Res. 1:337-347.

Chapman, H.D., and P.F. Pratt. 1961. Methods of analysis for soils, plants, and waters. Univ. Calif., Div. Agr. Sci., Riverside.

Daft, M.J., and T.H. Nicholson. 1966. Effect of Endogone mycorrhiza on plant growth. New Phytol. 65:343-350.

Devore, B., and M. Christensen. 1979. Effect of oil shale retort effluent on soil microfungi. J. Colo.-Wyo. Acad. Sci. 11:30.

Gerdemann, J.W. 1975. Vesicular-arbuscular mycorrhizae, p. 575-591. In: G. Torrey, and D.T. Nicholson (eds), The development and function of roots. Academic Press, New York.

Gerdemann, J.W., and T.H. Nicholson. 1963. Spores of mycorrhizal Endogone species extracted from soil by wet sieving and decanting. Trans. Brit. Mycol. Soc. 46:235-244.

Gerdemann, J.W., and J.M. Trappe. 1974. The Endogonaceae in the Pacific Northwest. Mycologia Memoir No. 5, New York Botanical Garden and the Mycological Soc. of Amer., Heffernan Press, Inc., Worcester, Mass.

Harbert, H.P., and W.A. Berg. 1974. Vegetative stabilization of spent oil shales. Tech. Rep. No. 4, Environ. Resources Center, Colo. State Univ., Fort Collins.

Hersman, L.E., and D.A. Klein. 1979. Retorted oil shale effects on soil microbiological characteristics. J. Environ. Qual. 8:520-524.

Horowitz, W. 1965. Official methods of analysis of the Association of Official Agricultural Chemists, 10th Ed. Ass. Off. Agr. Chem., Washington, D.C.

Institute for Land Rehabilitation. 1979. Final report on revegetation studies for disturbed areas and processed shale disposal sites. Agr. Exp. Sta., Utah State Univ., Logan.

Little, T.M., and F.J. Hills. 1972. Statistical methods in agricultural research. Univ. of California, Davis.

McKell, C.M. 1976. Achieving effective revegetation of disposed processed oil shale: A program emphasizing natural methods in an arid environment. Land Rehabilitation Series No. 1, Agr. Exp. Sta., Utah State Univ., Logan.

Menge, J.A. 1980. Mycorrhiza agriculture technologies. Food and Renewable Resources Program, Office of Technology, Washington, D.C.

Miller, R.M. 1979. Some occurrences of vesicular arbuscular mycorrhiza in natural and disturbed ecosystems of the Red Desert. Can. J. Bot. 57:619-623.

Phillips, J.M., and D.S. Hayman. 1970. Improved procedures for clearing roots and staining parasitic and vesicular-arbuscular mycorrhizal fungi for rapid assessment of infection. Trans. Brit. Mycol. Soc. 55:158-161.

Reeves, F.B., D. Wagner, T. Moorman, and J. Kiel. 1979. The role of endomycorrhizae in revegetation practices in the semi-arid west. I. A comparison of incidence of mycorrhizae in severely disturbed vs. natural environments. Amer. J. Bot. 66:6-13.

Schmehl, W.R., and B.D. McCaslin. 1973. Some properties of spent oil shale significant to plant growth, p. 27-43. In: R.J. Hutnik, and G. Davis (eds), Ecology and reclamation of devastated land, Vol. 2 Gordon and Breach Pub., New York. 